\title{
Hydrolysis of Aesculin and Phosphatase Production by Members of the Order Mycoplasmatales Which Do Not Require Sterol
}

\author{
CAROL O. WILLIAMS and RUTH G. WITTLER \\ Department of Bacterial Diseases, \\ Walter Reed Army Institute of Research, \\ Washington, D. C. 20012
}

\begin{abstract}
Two bacteriological methods, one to demonstrate phosphatase production and the other to demonstrate aesculin hydrolysis, were tested on sterol-requiring Mycoplasma and sterol-nonrequiring Acholeplasma strains to determine their utility in differentiating species. The phosphatase test, which gave weak and variable reactions with most of the sterolnonrequiring strains, was judged ineffectual for differentiating these strains. The aesculin test distinguished all Mycoplasma strains and Acholeplasma granularum, both of which gave negative reactions, from most Acholeplasma laidlawii strains and from Acholeplasma axanthum, which gave positive reactions.
\end{abstract}

The bacteriological characterization of Mycoplasma species by standardized methods was recently described by Aluotto et al. (1). Of the 22 species studied by these authors, half displayed distinctive patterns of biochemical activities. The remaining strains fell into groups containing several species with biochemically similar patterns. One such group included Mycoplasma gallisepticum, Mycoplasma histotropicum [now regarded as a strain of $\mathrm{Myco}$ plasma pulmonis (3)], Mycoplasma granularum, and Mycoplasma laidlawii. Application of the test of Razin and Tully (6) for determining cholesterol requirement readily permits differentiation of the sterol-requiring species in this group from the two sterol-nonrequiring species, $M$. granularum and $M$. laidlawii. [For these and other sterol-nonrequiring species, a new generic name, Acholeplasma, was recently proposed (4) and will be employed hereafter in this report.] Acholeplasma granularum and Acholeplasma laidlawii can be differentiated from each other by serological methods and gel electrophoretic patterns $(7,8)$, but a simple biochemical test for distinguishing them has been lacking. These strains react somewhat differently from each other when tested for phosphatase production and hemolysis; however, neither test alone is capable of distinguishing the species. The phosphatase reaction was reported to be weakly positive for $A$. laidlawii type A but negative for $A$. laidlawii type B and $A$. granularum (1). The type of hemolytic reaction for various $A$. laidlawii strains was examined (unpublished data) and found to vary from strain to strain. Now that a new and distinct species of Acholeplasma has been recognized (9), further biochemical tests for characterizing and differentiating them are all the more desirable.

A survey of biochemical reactions applicable to the problems of Mycoplasma and Acholeplasma characterization and differentiation pointed to aesculin hydrolysis as a possibility. A group of more than 22 types or representative strains of Mycoplasma and 32 Acholeplasma strains were, therefore, examined for ability to hydrolyze aesculin. In addition, the test for phosphatase activity was reexamined on all Acholeplasma strains to clarify and expand the findings of Aluotto et al. (1).

\section{MATERIALS AND METHODS}

Organisms and maintenance media. The organisms used by the authors were obtained from the American Type Culture Collection, from J. G. Tully, and from W. A. Clyde, Jr. Additional organisms from the collection of E. A. Freundt were tested by T. Sander at the University of Aarhus, Denmark. Strain designation and source of each organism are given in Table 1 .

All cultures were grown in Heart Infusion Broth (Difco) enriched with $20 \%(\mathrm{v} / \mathrm{v})$ sterile, heated (56 C for $30 \mathrm{~min}$ ) horse serum (Microbiological Associates, 
TABLE 1. Hydrolysis of aesculin by Mycoplasma and Acholeplasma species

\begin{tabular}{|c|c|c|c|}
\hline Species & Strain & Source & Reaction \\
\hline M. agalactiae & PG2 & Freundt $a$ & $-b$ \\
\hline M. arthritidis & PG6 (Preston) & ATCC $19611^{c}$ & - \\
\hline M. bovigenitalium & PG11 (B2) & ATCC 19852 & - \\
\hline M. canis & PG14 (C55) & ATCC 19525 & - \\
\hline M. edwardii & PG24 (C21) & ATCC 23462 & - \\
\hline M. felis & $\mathrm{CO}$ & ATCC 23391 & - \\
\hline M. fermentans & PG18 (G) & ATCC 19989 & - \\
\hline M. gallinarum & PG16 (Fowl) & ATCC 19708 & - \\
\hline M. gallisepticum & PG31 (X95) & ATCC 19610 & - \\
\hline M. gateae & $\mathrm{CS}$ & ATCC 23392 & - \\
\hline M. hominis & PG21 (H50) & ATCC 23114 & - \\
\hline M. hyorhinis & BTS-7 & ATCC 17981 & - \\
\hline M. iners & PG30 (M) & ATCC 19705 & - \\
\hline M. maculosum & PG15 (C27) & .ATCC 19327 & - \\
\hline \multicolumn{4}{|l|}{ M. mycoides subsp. } \\
\hline capri & PG3 & Freundt & $-b$ \\
\hline \multicolumn{4}{|l|}{ M. mycoides subsp. } \\
\hline mycoides & PG1 & Freundt & $-b$ \\
\hline M. neurolyticum & Sabin A & ATCC 19988 & - \\
\hline M. orale 1 & CH19299 & ATCC 23714 & - \\
\hline M. orale 2 & $\mathrm{CH} 20247$ & ATCC 23636 & - \\
\hline M. pneumoniae & FH & ATCC 15531 & _- \\
\hline M. pulmonis & PG34 (Ash) & ATCC 19612 & - \\
\hline M. salivarium & PG20 (H110) & ATCC 23064 & - \\
\hline Mycoplasma sp. & C30KS-1 & ATCC 15718 & - \\
\hline Mycoplasma sp. & Navel & ATCC 15497 & - \\
\hline Mycoplasma sp. & $67-166$ & ATCC 23243 & - \\
\hline M. spumans & PG13 (C48) & ATCC 19526 & - \\
\hline A. axanthum & S-743 & ATCC 25176 & + \\
\hline A. granularum & BTS-39 & ATCC 19168 & - \\
\hline A. granularum & BTS-39 & Tully $d$ & - \\
\hline A. granularum & 39D & Tully & - \\
\hline A. granularum & $31 \mathrm{~B}-1$ & Tully & - \\
\hline A. granularum & Friend & Tully & - \\
\hline A. laidlawii & Laidlaw A & ATCC 14089 & + \\
\hline A. laidlawii & Laidlaw B & ATCC 14192 & + \\
\hline A. laidlawii & PG8 (Sewage A) & ATCC 23206 & + \\
\hline A. laidlawii & PG9 (Sewage B) & ATCC 23217 & + \\
\hline A. laidlawii & Laidlaw A (F1) & Freundt & $+b$ \\
\hline A. laidlawii & Laidlaw B (F8) & Freundt & $+b$ \\
\hline A. laidlawii & Algen & Tully & - \\
\hline A. laidlawii & Mist & Tully & + \\
\hline A. laidlawii & L & Tully & + \\
\hline A. laidlawii & PG10 (B-15) & Tully & + \\
\hline A. laidlawii & $643-\mathrm{N}$ & Tully & + \\
\hline A. laidlawii & $\mathrm{J}-18 \mathrm{~S}$ & Tully & + \\
\hline A. laidlawii & Haig 179-L (clone 1) & Tully & - \\
\hline A. laidlawii & Haig $179-\mathrm{L}$ (clone 6 ) & Tully & _- \\
\hline A. laidlawii & PG47 (3M-152) & Tully & + \\
\hline A. laidlawii & H3-10 & Tully & + \\
\hline
\end{tabular}


TABLE 1. Hydrolysis of aesculin by Mycoplasma and Acholeplasma species (Con't.)

\begin{tabular}{lccc}
\hline Species & Strain & Source & Reaction \\
\hline A. laidlawii & STR & Tully & + \\
A. laidlawii & OR & Tully & + \\
A. laidlawii & Flamm 583 & Tully & + \\
A. laidlawii & R-4 & Tully & + \\
A. laidlawii & Granoff 8 & Tully & - \\
A. laidlawii & TC7277 & Tully & + \\
A. laidlawii & R-1 & Tully & + \\
A. laidlawii & PG5 & Tully & + \\
A. laidlawii & B4 & Tully & + \\
A. laidlawii & KHS & Tully & + \\
A. laidlawii & S & Clyde & + \\
A. laidlawii subsp. & & & \\
inocuum & A4H3-10 & ATCC 25937 & + \\
\hline
\end{tabular}

$a$ Cultures in the collection of E. A. Freundt, University of Aarhus, Aarhus, Denmark.

$b$ Test conducted by Torben Sander at University of Aarhus, Aarhus, Denmark.

$c$ Cultures received from the American Type Culture Collection, Rockville, Md. Md.

$d$ Cultures received from Joseph G. Tully, National Institute of Allergy and Infectious Diseases, Bethesda,

$e$ Cultures received from Wallace A. Clyde, Jr., University of North Carolina School of Medicine, Chapel Hill, N.C.

Inc., Bethesda, Md.) and $10 \%(\mathrm{v} / \mathrm{v})$ of a $25 \%(\mathrm{w} / \mathrm{v})$ fresh yeast extract solution (Grand Island Biological Co., Grand Island, N.Y.). Incubation was at $37 \mathrm{C}$ for $24 \mathrm{hr}$.

Test media and methods. The phosphatase test method was essentially that of Aluotto et al. (1). The medium was composed of Heart Infusion Agar (Difco), 20\% (v/v) sterile, heated (56 C for $30 \mathrm{~min}$ ) horse serum, $10 \%(\mathrm{v} / \mathrm{v})$ of a $25 \%(\mathrm{w} / \mathrm{v})$ fresh yeast extract solution, and $1 \%(\mathrm{v} / \mathrm{v})$ of a sterile $1 \%(\mathrm{w} / \mathrm{v})$ stock solution of the sodium salt of phenolphthalein diphosphate (Sigma Chemical Co., St. Louis, Mo.) Plates were inoculated in triplicate with $24-\mathrm{hr}$-old broth cultures and incubated at $37 \mathrm{C}$. Readings were made after 3,7 , and 14 days of growth. The presence of free phenolphthalein was tested for on each occasion by flooding the surface of one plate of the triplicate set with $5 \mathrm{~N} \mathrm{NaOH}$. A red color in the 3-or 7-day-old plate, with the coloration becoming more intense in the 7-or 14-day-old plate, respectively, was recorded as positive. A faint red color produced only in the 14-day-old plate was recorded as weakly positive.

Aesculin hydrolysis was determined by a modification of the method described by Cowan and Steel (2) using Heart Infusion Agar (Difco) supplemented with $20 \%(\mathrm{v} / \mathrm{v})$ sterile, heated $(56 \mathrm{C}$ for $30 \mathrm{~min}$ ) horse serum, $10 \%(\mathrm{v} / \mathrm{v})$ of a $25 \%(\mathrm{w} / \mathrm{v})$ fresh yeast extract solution, $0.1 \%(\mathrm{w} / \mathrm{v})$ aesculin $(\mathrm{BBL})$, and $0.05 \%(\mathrm{w} / \mathrm{v})$ ferric citrate (Fisher Scientific Co., Fair Lawn, N.J.). Plates were inoculated with 24 -hr-old broth cultures, incubated at $37 \mathrm{C}$, and read at 3,7 , and 14 days. The development of a black color, whether intense or faint, in the test medium was indicative of a positive reaction.
Controls. Test cultures were examined for freedom from contamination by inoculation into Thioglycollate fluid medium (BBL) to which $20 \%(\mathrm{v} / \mathrm{v})$ sterile, heated horse serum had been added, onto an agar gel of the broth growth medium, and onto a blood-agar plate. Gram stained preparations of all cultures were examined for contaminants.

Organisms known to give positive or negative reactions were included as controls for both the phosphatase and the aesculin tests. To ensure that test organisms and not media constituents were responsible for positive reactions, test media were inoculated with the sterile infusion-serum-yeast broth medium.

For the aesculin test, cultures were also grown on test media from which only aesculin was excluded, from which only ferric citrate was excluded, and from which both substrates were excluded. In all cases, reactions were seen only on the complete test medium containing both substrates.

\section{RESULTS AND DISCUSSION}

Phosphatase production. A few Acholeplasma strains gave consistent phosphatase results. A. granularum strains $31 \mathrm{~B}-1$ and Friend were negative; $A$. laidlawii type A strains, Laidlaw A, PG8, Laidlaw A (F1), OR, Flamm 583 , and R-4, and type B strains, Granoff 8 and TC7277, were consistently weakly positive. However, most Acholeplasma strains reacted with marked inconsistency; they exhibited weakly positive reactions some of the time and negative reactions at other times. The explanation for such variation is not clear. The positive 
control organism, Mycoplasma arthritidis strain Preston, like the other Mycoplasma species that have exhibited a positive reaction, produced an intense red color by the seventh day of incubation. The negative control organism, Mycoplasma gallisepticum strain S6, was negative at each reading. Uninoculated control plates containing the test substrate were negative at 7 days but did occasionally exhibit a faint reddening after 14 days of incubation, indicating partial breakdown of the test substrate with liberation of some free phenolphthalein. Thus, the weakly positive reactions that appeared for a majority of the Acholeplasma strains might have been false positive reactions, although the appropriate control plates were negative at the time. Detection of phosphatase activity in Acholeplasma strains by the particular method here used cannot be considered reliable. Since only 2 of 32 of those strains gave frankly negative reactions, and since an explanation for the late and variable reactions of the others is required, production of phosphatase by these organisms needs further investigation.

Aesculin hydrolysis. The results of tests for hydrolysis of aesculin are given in Table 1. Twenty-six Mycoplasma strains representing 22 or more species were negative. Also negative were four $A$. granularum strains, including two different culture lines of BTS-39. Twenty-four strains of $A$. laidlawii and the new sterolnonrequiring species $A$. axanthum (9) gave consistently positive reactions for aesculin hydrolysis. Most reactions developed by the third day, and only a few strains required as long as 7 days to produce the color change. Three remaining $A$. laidlawii strains, Algen, Haig 179-L (clones 1 and 6), and Granoff 8 , were judged negative, although a very slight blackening of the test medium could occasionally be seen at the 14-day reading. Tully and Razin (7) noted that two of these strains showed atypical fermentative results, i.e., Haig 179-L attacked neither glucose nor mannose, and Granoff 8 attacked both carbohydrates in contrast to Algen and other $A$. laidlawii strains that attacked glucose but not mannose. By fluorescent-antibody techniques (7) and by gel electrophoretic analysis (8), Haig 179-L, Granoff 8 , and Algen were identified as $A$. laidlawii strains. Whether their atypical behavior on the glucoside aesculin and perhaps on - the above-mentioned carbohydrates is meaningful for taxonomic purposes is not yet clear.

Apart from the above exceptions, hydrolysis of aesculin appears to be characteristic for two Acholeplasma species: A. laidlawii and A. axanthum. Henrikson and Smith (5) examined strains of three Mycoplasma species, one fermentative, sterol-nonrequiring ( $A$. laidlawii), one fermentative, sterol-requiring $(M$. gallisepticum), and one nonfermentative, sterolrequiring $(M$. hominis), for glucosidase activity by using several glucosides other than aesculin. They found that $M$. hominis hydrolyzed none of the glucosides tested, whereas $A$. laidlawil and $M$. gallisepticum hydrolyzed certain of the $\beta$-glucosides. In contrast, the strain of $M$. gallisepticum studied here showed no glucosidase activity for aesculin.

Tully and Razin (8) recently showed that $A$. laidlawii and $A$. granularum could be differentiated from $A$. axanthum by the ability of the two former species to produce pigmented carotenoids, an ability that the latter species lacked. Tully and Razin (8), therefore, suggested that species differentiation among sterol-nonrequiring strains might be based on (i) serological characteristics, (ii) unique properties of lipid metabolism such as lack of pigmented carotenoids, and (iii) additional nutritional and biochemical distinctions. Based on carotenoid production and aesculin hydrolysis alone, each of the three species presently comprising the genus Acholeplasma appears distinct. A. laidlawii is aesculin positive, carotenoid positive; $A$. granularum is aesculin negative, carotenoid positive; and $A$. axanthum is aesculin positive, carotenoid negative. Thus, the ability to hydrolyze aesculin provides a simple and useful differential biochemical test for the species of the genus Acholeplasma inasmuch as all Mycoplasma species examined to date are negative in this test.

\section{ACKNOWLEDGMENTS}

We express our gratitude to E. A. Freundt and T. Sander for providing us with phosphatase and aesculin test results for $M$. agalactiae, $M$. mycoides subsp. mycoides, $M$. mycoides subsp. capri, and $A$. laidawii strains $F 1$ and F8. We are indebted to Margaret C. Norman of the American Type Culture Collection and Walter Reed Army Institute of Research, Washington, D.C., who supplied well-grown cultures from the ATCC for use in this study. We thank J. G. Tully and W. A. Clyde, Jr., for the cultures kindly furnished by them.

\section{LITERATURE CITED}

1. Aluotto, B. A., R. G. Wittler, C. O. Williams, and J. E. Faber. 1970. Standardized bacteriologic techniques for the characterization of Mycoplasma species. Int. J. Syst. Bacteriol. 20:35-58.

2. Cowan, S. T., and K. J. Steel. 1965. Manual for the identification of medical bacteria. Cambridge University Press, London.

3. Edward, D. G. ff., and E. A. Freundt. 1969. Classification of the Mycoplasmatales, $p$. 147-200. In L. Hayflick (ed.), The Mycoplasma- 
tales and the L-phase of bacteria. AppletonCentury-Crofts. New York.

4. Edward, D. G. ff., and E. A. Freundt. 1970. Amended nomenclature for strains related to Mycoplasma laidlawii. J. Gen. Microbiol. 62:1-2.

5. Henrikson, C. V., and P. F. Smith. 1964. $\beta$-Glucosidase activity in mycoplasma. J. Gen. Microbiol. $37: 73-80$.

6. Razin, S., and J. G. Tully. 1970. Cholesterol requirement of mycoplasmas. J. Bacteriol. 102:306-310.
7. Tully, J. G., and S. Razin. 1968. Physiological and serological comparisons among strains of $\mathrm{Myco}$ plasma granularum and Mycoplasma laidlawii. J. Bacteriol. 95:1504-1512.

8. Tully, J. G., and S. Razin. 1969. Characteristics of a new sterol-nonrequiring Mycoplasma. J. Bacteriol. 98:970-978.

9. Tully, J. G., and S. Razin. 1970. Acholeplasma axanthum, sp. n.: a new sterol-nonrequiring member of the Mycoplasmatales. J. Bacteriol. 103: $751-754$. 